\title{
Prognostic values of ETS-1, MMP-2 and MMP-9 expression and co-expression in breast cancer patients
}

\author{
V. PUZOVIC ${ }^{1, *}$, I. BRCIC ${ }^{2}$, I. RANOGAJEC ${ }^{3}$, J. JAKIC-RAZUMOVIC ${ }^{2}$ \\ ${ }^{1}$ Department of pathology, cytology and forensic medicine, General Hospital Dubrovnik, Roka Misetica bb, Dubrovnik, Croatia; ${ }^{2}$ Department \\ of Pathology, Zagreb University Hospital Center, Kispaticeva 12, 10000 Zagreb, Croatia; ${ }^{3}$ Department of Clinical Cytology, Policlinic SUNCE, \\ Trnjanska cesta 108, 10000 Zagreb, Croatia
}

*Correspondence: velibor.puzovic@gmail.com

Received October 8, 2013 / Accepted November 28, 2013

\begin{abstract}
The aim of this study was to analyse expression of ETS-1 protein and two gelatinases (MMP-2 and MMP-9) and their possible prognostic value in breast carcinoma patients, as well as correlation of their expression with other known prognostic factors such as tumor size, grade, vascular invasion, steroid receptor values, HER2 values and proliferative index. The expression of MMP-2, MMP-9 and ETS-1 was immunohistochemicaly analysed in 121 consecutive primary breast carcinoma patients who underwent surgery at the Clinical Hospital Centre Zagreb during 2002. Three representative areas from each tumor paraffin blocks were taken and arranged on a recipient paraffin block with predefined coordinates for simultaneous analyses of multiple tissue samples (TMA). ETS-1, MMP-2 and MMP-9 expression and co-expression were correlated with other clinico-pathological parameters and based on the available clinical follow up data survival analysis was performed.

The ETS-1 protein is found to be expressed in tumor cell nuclei and cytoplasm as well as in stromal lymphocytes, fibroblasts and endothelial cells. MMP-2 and MMP-9 were found to be expressed in cytoplasm of both, tumor and stromal cells. For our analysis only tumor cell expression was used for statistical analysis. We found 56,2\% ETS-1 positive tumors, 77,7\% were MMP-2 positive, and MMP-9 was expressed in 90\% of primary breast carcinomas. There were no significant correlations between MMP-s expression and other patohistological prognostic factors, but expression of ETS-1 was significantly correlated with higher tumor size and grade, as well as with negative steroid receptors. Co-expression of MMP-2, MMP-9 and ETS- 1 was found in 40,5\% of tumors, and more commonly was found in tumors larger than $2 \mathrm{~cm}$, high grade tumors, and steroid receptor negative tumors. In univariate analysis, statistically significant negative impact on overall survival (OS) had tumor size, nuclear and tumor grade, ETS-1 expression in tumor cells, co-expression of ETS-1 either with MMP-2 or MMP-9, as well as co-expression of ETS-1, MMP-2 and MMP-3. Disease free survival (DFS) was significantly shorter in patients with tumors greater than $2 \mathrm{~cm}$, ETS-1 positive tumors, ETS-1 and MMP-2 or MMP-9 co-expressed tumors, and additionally in tumors with ETS-1, MMP-2 and MMP-9 co-expression. These results suggest that expression of ETS-1 as well as MMP-2, MMP-9 and ETS-1 co-expression might be used as a poor prognostic factor in breast cancer patients.
\end{abstract}

Key words: breast cancer, ETS-1, gelatinases, transcription factor, prognosis

Today it is an undeniable fact that despite new discoveries in the field of oncology and excellent screening programs, breast cancer is the major cause of cancer related deaths in

Abbreviations: ETS-1: E26 transformation specific -1 transcription factor, MMP-2: matrix metalloproteinase 2, gelatinase A, MMP-9: matrix metalloproteinase 9, gelatinase B, TMA: tissue microarray, OS: overall survival, DFS: disease-free survival, HER2: human epidermal factor receptor 2, ER: estrogen receptors, PR: progesterone receptors, BRCA1: breast cancer 1, BRCA2: breast cancer 2 women worldwide [1]. It is well known that up to $10 \%$ of all breast cancers are hereditary and caused partly by mutations of BRCA1 and BRCA2 genes [2]. However, vast majority of patients with breast cancer belong to the group of so-called sporadic breast carcinoma. These facts stimulates the entire medical clinical and research population to try to discover new prognostic factors to be able to understand the breast carcinoma pathogenesis which can lead us to better treatment and longer survival of patients. 
One of the genetic factors that play a role in the progression and prognosis of breast cancer is a transcription factor ETS-1 [3-7]. It belongs to the ETS protein family, biggest family of human transcription factors [5]. Altered expression of ETS-1 transcription factor is often found in tumors [5-9]. In breast cancer, expression of ETS-1 protein is associated with oncogenesis, tumor progression, metastatic potential and survival [3,10-11]. There is also evidence that drug resistant breast cancer cells overexpress ETS-1 gene [12]. ETS-1 is overexpressed in ductal epithelial cells in malignant transformation, and is one of the factors associated with tumor growth and differentiation of breast carcinomas [13]. It has been also shown that binding sites for ETS proteins are promotors of many DNA genes that among others encode enzymes such as matrix metalloproteinase-1,2,3,7,9 [14-17]. Degradation of the basement membrane is the main process of tumor invasion and development of the metastases [18] and MMPs are enzymes that play an important role in that process [19]. MMPs are overexpressed in a wide range of malignant tumors. The correlation between their expression and tumor aggressiveness, clinical stage, and prognosis has been demonstrated [20]. Within the MMP family, MMP-2 (gelatinase A, 72kDa) and MMP-9 (gelatinase B, 92kDa) are involved in collagen IV degradation, the main component of the basement membrane [18-19]. The overexpression of MMP-2 and MMP-9 was also found in some breast cancers, with proved correlation with local invasion, metastatic disease and prognosis [19, 21-27]. Since the binding site for ETS-1 transcription factor is present in MMP-2 and MMP-9 promotor region [28-29], the positive correlation between expressions of ETS-1 and gelatinases in many malignant tumors including breast cancer was found [15-17].

The goal of this study was to analyse expression and coexpression of ETS-1 protein and two gelatinases (MMP-2 and MMP-9) in sense of their possible prognostic value in breast carcinoma patients in our population, as well as correlation of their expression with other traditional prognostic factors such as tumor size, grade, vascular invasion, lymph node status, steroid receptor and HER2 expression and proliferative index.

\section{Materials and methods}

In this study we included 209 consecutive primary breast carcinoma patients diagnosed and treated in Clinical Hospital Centre Zagreb during 2002. Since the study was designed that only patients with invasive ductal carcinomas (NST) and patients with completed clinical follow-up data were included, the final number of patients was 121. All patients had no distant metastases at the time of diagnosis. For each patient pathohistological data (tumor size, nuclear and histologic grade, lymph node status, presence of vascular invasion, steroid receptor and HER-2/neu status) were reanalyzed. Proliferative index was estimated by the immunohistochemical assessment of the nuclear antigen $\mathrm{Ki}-67$. Specimens with HER-2/neu expression 2+ were further analyzed using in situ technique (dual-SISH) for the evaluation of gene amplification.

Three representative areas from each tumor paraffin block were taken and arranged on a recipient paraffin block with predefined coordinates for simultaneous analysis of multiple tissue samples (tissue microarray, TMA). Tissue microchips were cut into 4-5 microns thick sections and stained with standard immunohistochemical avidin-biotin immunoperoxidase method using anti-ETS-1 antibody, anti-MMP-2 and antiMMP-9 (Novocastra, UK) in autostainer (Autostainer, Dako, Denmark). All slides were analysed using light microscope and the results of staining were presented as immunohistochemical score. According to the percentage of positive tumor cells for each tumor triplet average points were awarded: 0 -negative, $1=1-10 \%, 2=10-50 \%, 3=$ more than $50 \%$ of stained cells [13]. Multiplying the intensity of staining $(0,1,2,3)$ with the number of points assigned to the percentage of stained cells the score value was established from 0 to 9. MMP-2 and MMP-9 expressions were calculated for tumor cells.

Immunohistochemical scores were evaluated by two pathologists who were unaware of patients' patohistological and follow-up data. Discrepancies between the observers were found in $10 \%$ of the cases, they were re-examined, and consensus was reached on further review.

ETS-1, MMP-2 and MMP-9 expressions and co-expressions were correlated with other clinicopathological parameters. Based on the available clinical follow-up data survival analysis was done (overall survival- OS and disease-free survivalDFS).

Statistical analysis was done using STATISTICA software. In order to estimate the impact of prognostic factors on OS and DFS we used the Kaplan-Meier method for up to 124 months of follow-up and performed univariate and multivariate Cox regression analysis. The score for ETS-1, MMP-2, MMP-9 immunoreactivity was compared with other prognostic variables by chi-square test. The same test was used for comparison between ETS-1/MMP-2/MMP-9 co-expression with other prognostic factors, and $\mathrm{p}<0.05$ was considered statistically significant.

\section{Results}

Patient clinical characteristics and immunohistochemical analysis. In this study 121 patients were enrolled. Median age was 57 years (range 30 to 83 years,). The median tumor size was $2,35 \mathrm{~cm}$ (range $0,5-10 \mathrm{~cm}$, median $2 \mathrm{~cm}$ ) and the median follow-up time was 80, 6 months (range 9-124 months). All patients' clinicopathological data are summarized in Table 1. In our material $56.2 \%$ of breast carcinoma patients had ETS1 positive tumors, while MMP-2 and MMP-9 positivity was found in $77.7 \%$ and $90 \%$ of tumors respectively (Figure 1). Co-expression of all three investigated parameters was found in $40,5 \%$ patients.

Immunoreactivity of ETS-1, MMP-2 and MMP-9 in relation to traditional prognostic factors is shown in Table 2. 
Table 1. Clinical and pathological data for $\mathbf{1 2 1}$ breast carcinoma patient

\begin{tabular}{|c|c|}
\hline Variable & Number of patients(\%) \\
\hline \multicolumn{2}{|l|}{ Menopausal status } \\
\hline Premenopausal & $53(43,8)$ \\
\hline Postmenopausal & $68(56,2)$ \\
\hline \multicolumn{2}{|l|}{ Histological grade } \\
\hline 1 & $17(14,04)$ \\
\hline 2 & $56(46,28)$ \\
\hline 3 & $45(37,20)$ \\
\hline \multicolumn{2}{|l|}{ Nuclear grade } \\
\hline 1 & $9(7,43)$ \\
\hline 2 & $66(54,54)$ \\
\hline 3 & $45(37,19)$ \\
\hline \multicolumn{2}{|l|}{ ER } \\
\hline Positive & $82(67,77)$ \\
\hline Negative & $38(31,40)$ \\
\hline Not done & $1(0,83)$ \\
\hline \multicolumn{2}{|l|}{ PR } \\
\hline Positive & $65(53,72)$ \\
\hline Negative & $55(45,45)$ \\
\hline Not done & $1(0,83)$ \\
\hline \multicolumn{2}{|l|}{ HER-2 } \\
\hline Positive (3,dualSISH) & $27(22,32)$ \\
\hline Negative $(0,1,2)$ & $94(77,68)$ \\
\hline \multicolumn{2}{|l|}{ Ki67 } \\
\hline Low & $86(71,07)$ \\
\hline Intermediate & $20(16,53)$ \\
\hline High & $12(9,92)$ \\
\hline Missing & $3(2,48)$ \\
\hline \multicolumn{2}{|l|}{ Vascular invasion } \\
\hline No & $115(95,04)$ \\
\hline Yes & $6(4,95)$ \\
\hline \multicolumn{2}{|l|}{ Lymph node status } \\
\hline Positive & $42(34,71)$ \\
\hline Negative & $57(47,1)$ \\
\hline Not operated & $22(18,18)$ \\
\hline \multicolumn{2}{|l|}{ Surgery } \\
\hline Breast saving procedure & $77(63,64)$ \\
\hline Mastectomy & $44(36,36)$ \\
\hline \multicolumn{2}{|l|}{ Chemotherapy } \\
\hline Yes & $90(74,38)$ \\
\hline No & $31(25,61))$ \\
\hline \multicolumn{2}{|l|}{ Endocrine therapy } \\
\hline Yes & $85(70,25)$ \\
\hline No & $34(28,1)$ \\
\hline \multicolumn{2}{|l|}{ Radiotherapy } \\
\hline Yes & $81(66,95)$ \\
\hline No & $40(33,05)$ \\
\hline \multicolumn{2}{|l|}{ Relapse } \\
\hline Yes & $38(31,40)$ \\
\hline No & $83(68,60)$ \\
\hline \multicolumn{2}{|l|}{ Death of the patient } \\
\hline Yes & $31(25,61)$ \\
\hline No & $90(74,38)$ \\
\hline
\end{tabular}

Table 2. Correlation of ETS-1, MMP-2 and MMP-9 expression in tumour cells with other clinicopathological data

\begin{tabular}{|c|c|c|c|c|}
\hline & ETS-1 & MMP-2 & MMP-9 & $\begin{array}{c}\text { ETS1/MMP2/ } \\
\text { MMP9 }\end{array}$ \\
\hline Age & NS & NS & NS & NS \\
\hline Tumour size & $0,0105^{\star}$ & NS & NS & $0,0065^{\star}$ \\
\hline Nuclear grade & NS & NS & NS & $0,032^{\star}$ \\
\hline Histological grade & $0,0430^{*}$ & NS & NS & $0,0049^{*}$ \\
\hline Lymph node & NS & NS & NS & NS \\
\hline ER & $0,0476^{*}$ & NS & NS & $0,013^{*}$ \\
\hline PR & $0,0123^{*}$ & NS & NS & $0,0058^{\star}$ \\
\hline HER-2 & NS & NS & NS & NS \\
\hline Ki67 & NS & NS & NS & NS \\
\hline
\end{tabular}

NS-not significant

*- statistically significant $(\mathrm{p}<0,05)$

ETS-1 expression in tumor cells was correlated with tumor size, tumor grade and steroid receptors expression. There were no significant correlations between MMP-s expression and other patohistological parameters. Concerning vascular invasion, in our study there were only six patients with definitive vascular invasion. Therefore, we were unable to calculate any correlation between expression of our proteins and vascular invasion. The observed MMP-2, MMP-9 and ETS-1 co-expression in tumor cells was more common in tumors larger than $2 \mathrm{~cm}(0,4-7.0 \mathrm{~cm}$, mean $2,35 \mathrm{~cm}, \mathrm{p}=$ $0.0065)$, in tumors with histological and nuclear grade 3 as well as in ER and PR negative tumors. Co-expressions were not associated with lymph node metastasis, HER-2/neu status or Ki67 proliferation index.

Follow-up and survival analysis. Survival was calculated during the follow-up period of 9-124 (average 80,6) months. In that period 31 patients died of breast cancer related death. In Kaplan Meier analysis patients with ETS-1 positive tumors had shorter OS than those with ETS- 1 negative tumors ( $\mathrm{p}=0,0056$, Figure 2). DFS was also compared to the expression of ETS1, MMP-2 and MMP-9 in tumor cells. The DFS was shorter in patients with ETS- 1 positive tumors $(p=0,0002$, Figure 3$)$. No significant differences in DFS were found between MMP2 and MMP-9 positive and negative tumors $(\mathrm{p}=0,723$ and $\mathrm{p}=0,335$, respectively). There was strong impact of tumor cells co-expression of ETS-1, MMP-2 and MMP-9 on OS and DFS (Figure 4 and 5).

Factors with statistically significant correlations with OS and DFS in univariate Cox analysis are summarized in Table 3 and 4 . However, we were not able to confirm these findings in multivariate analysis.

\section{Discussion}

Due to breast cancer high ratio of recurrence and mortality, great emphasis is placed on the discovery of new prognostic factors that would allow the separation of the subset of pa- 


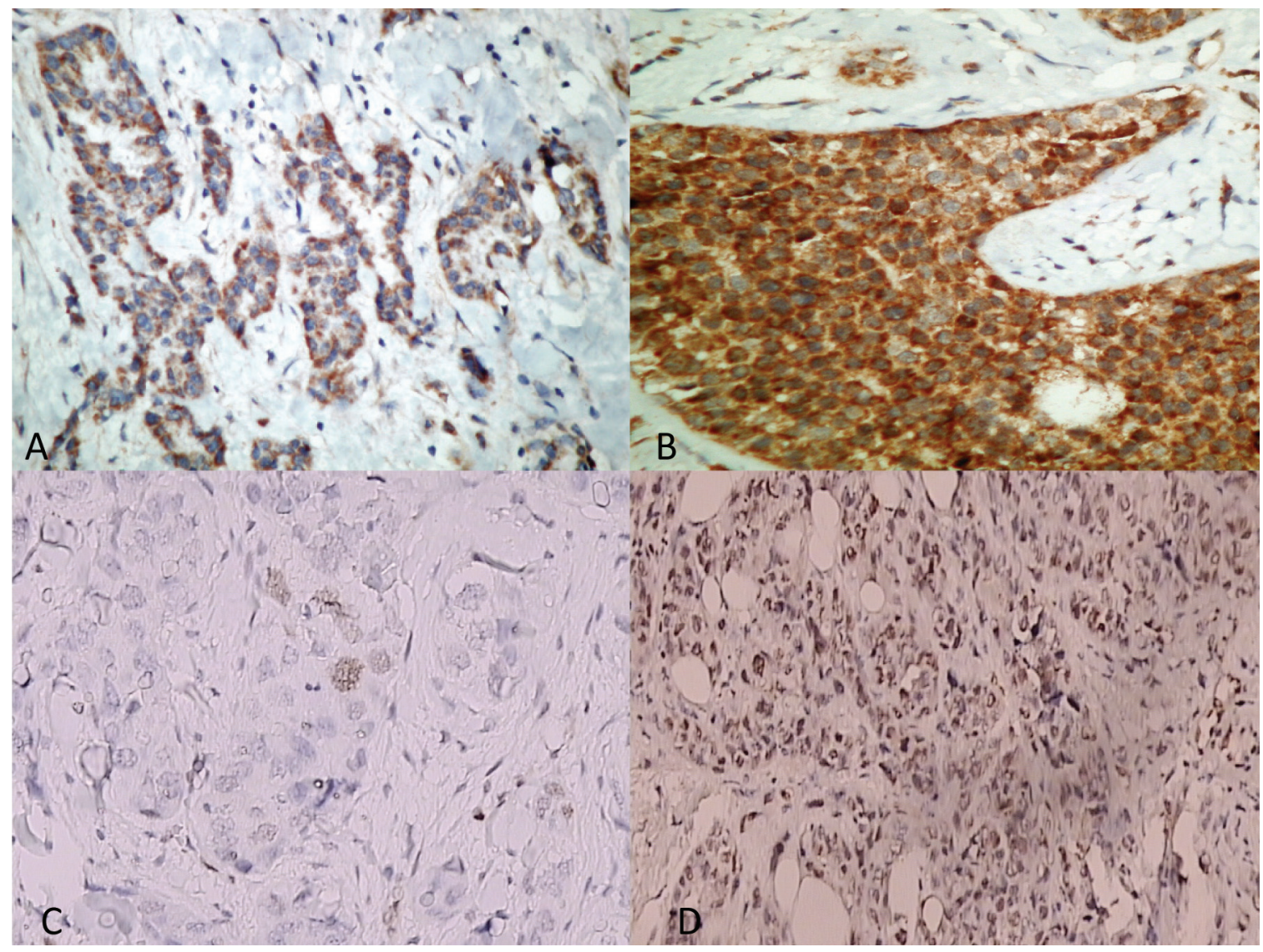

Figure 1. A) MMP-2 positive breast carcinoma tumour cells. Immunohistochemistry with anti-MMP-2 antibody. Counterstaining hematoxilin X 200. B) MMP-9 positive breast carcinoma tumour cells. Immunohistochemistry with anti-MMP-9 antibody. Counterstaining hematoxilin X 400. C) ETS-1 positive breast carcinoma tumour cells, low expression. Immunohistochemistry with anti-ETS-1 antibody. Counterstaining hematoxilin X 400. D) ETS-1 positive breast carcinoma tumour cells, high expression. Immunohistochemistry with anti-ETS-1 antibody. Counterstaining hematoxilin X 400.

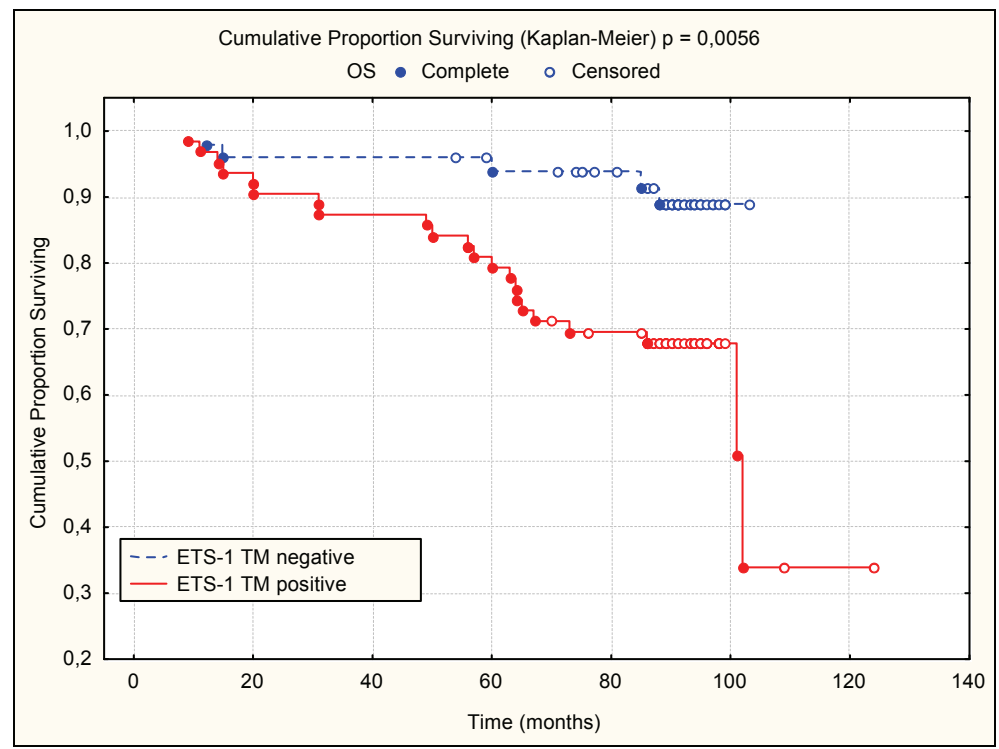

Figure 2. OS curves for ETS-1 negative and positive breast carcinoma patients 


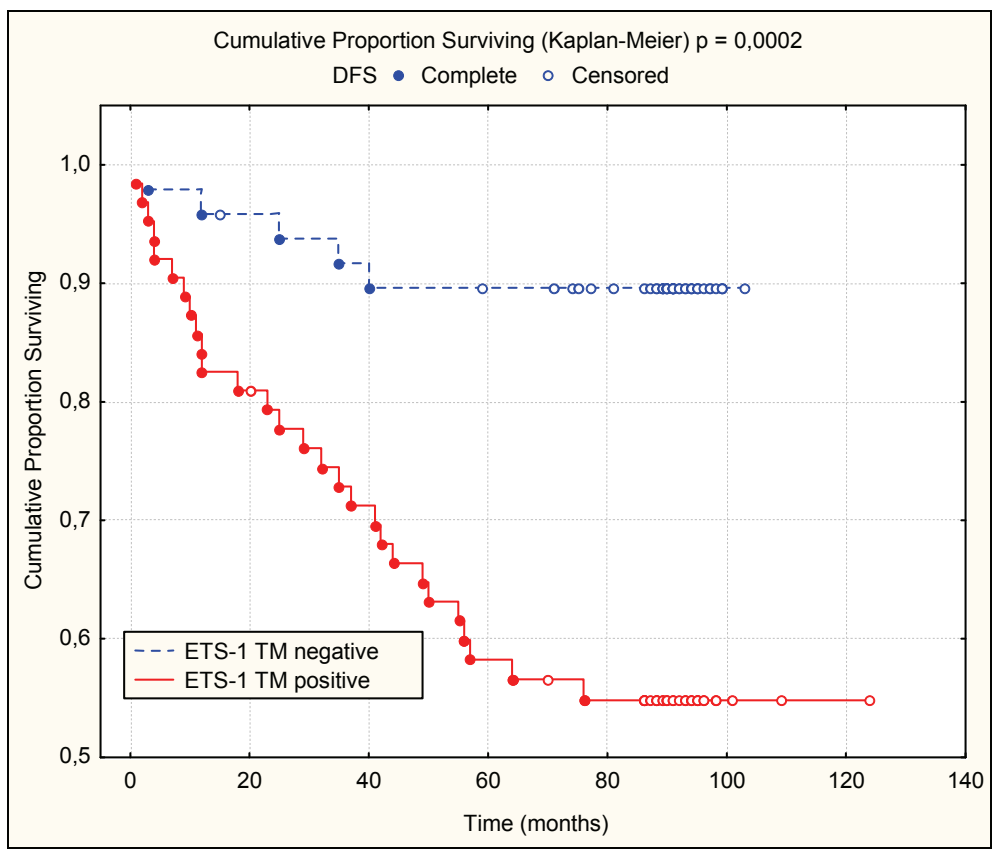

Figure 3. DFS for ETS-1 negative and positive breast carcinoma patients

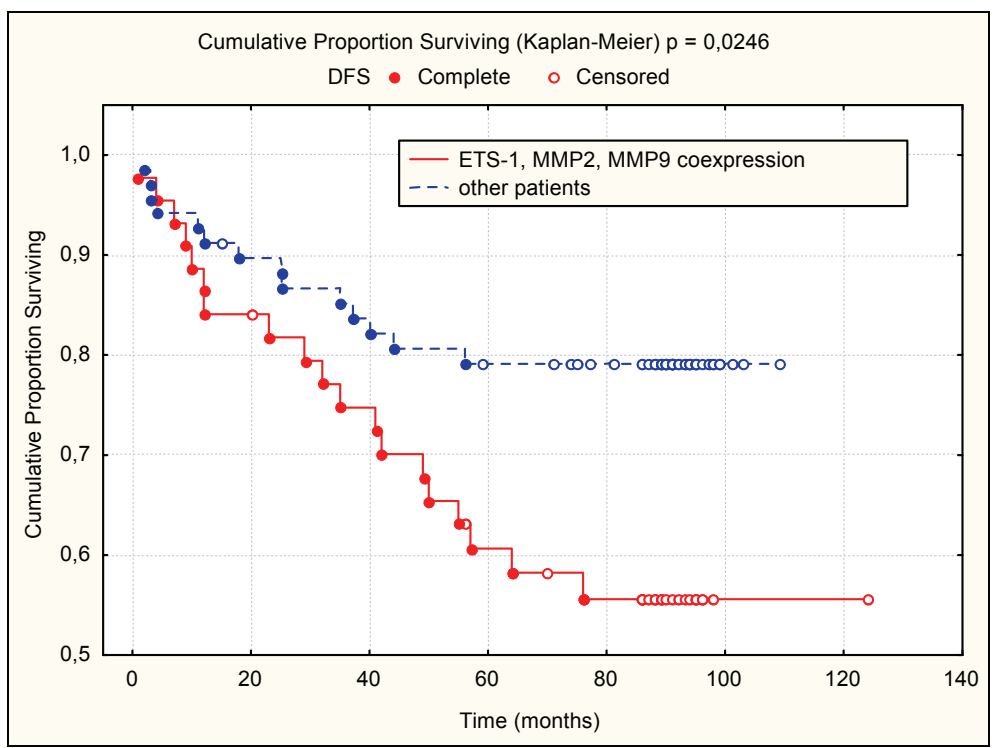

Figure 4. DFS curves for ETS-1, MMP-2 and MMP-9 co-expression in breast carcinoma patients in comparison with other patients

tients that would require more aggressive adjuvant treatment. Primary tumor characteristics are increasingly important in that selection, and therefore we wanted to investigate expression and co-expression prognostic values of ETS-1 and two gelatinases in breast cancer tumor cells.

ETS-1 belongs to biggest family of transcription factors [5]. Some studies have shown its correlation with prognosis, pathogenesis and metastatic potential of many malignant tumors including breast cancer [3-7, 15,17]. These studies suggested a higher expressions of ETS-1 in malignant tumors, but despite these results the true role of transcription factor ETS-1 remains unclear. In study published by Span et al. it has been shown that ETS-1 is a prognostic factor for relapse-free survival for breast cancer patients [3]. Our data confirmed their conclusion.

Controversies about MMPs impact on cancer progression are also reported. There are reports of tumor regression 


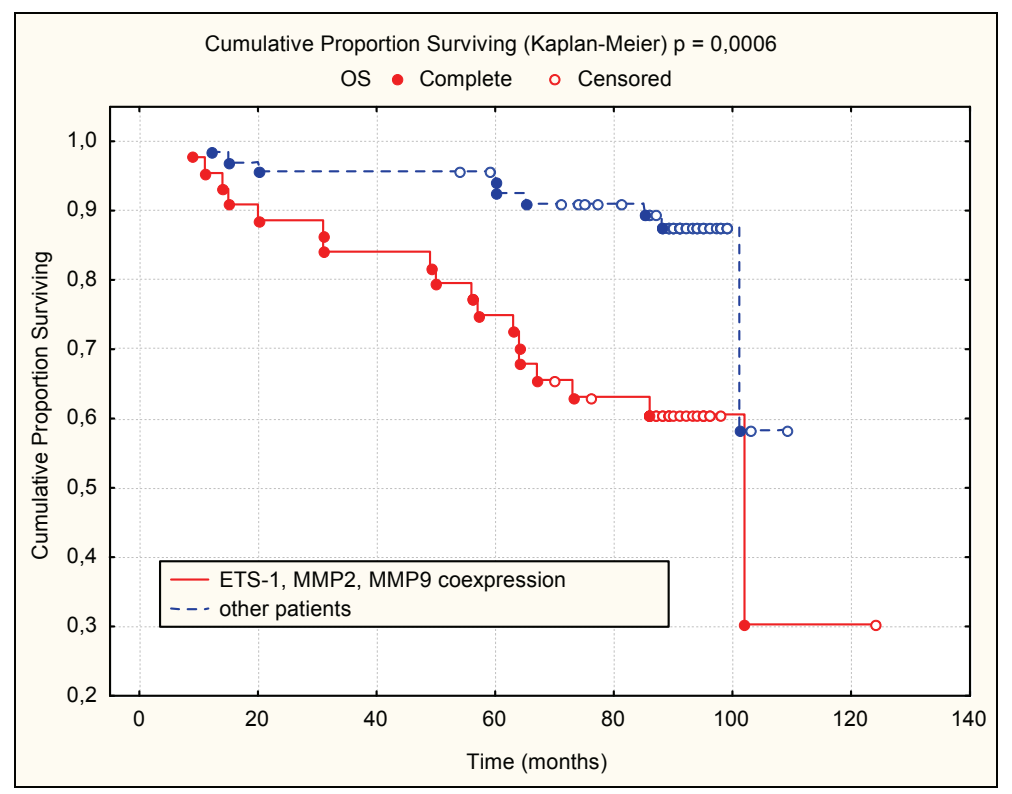

Figure 5. OS for breast carcinoma patients with ETS-1, MMP-2 and MMP-9 co-expression in comparison with other patients

with overexpression of MMP-9 [30]. Other published studies showed a correlation between overexpression of MMP-2 and MMP-9 activity and tumor initiation and progression $[19,21$, $23-27,31,32]$. However, no consensus in the literature regarding their prognostic significance is established. Some authors found a relationship between gelatinases in tumor cells and a poor survival rate $[21,23,26-27,33]$. Other reported no

Table 3. Influence of investigated parameters on DFS of breast carcinoma patients

\begin{tabular}{lcccc}
\hline \multirow{2}{*}{ Factors } & Odds $\begin{array}{c}\text { \% confidence } \\
\text { intervals }\end{array}$ & p \\
\cline { 2 - 4 } & Ratio & low & high & \\
\cline { 2 - 4 } Tumour size & 2,47 & 1,07 & 5,72 & $\mathbf{0 , 0 3 4 8}^{*}$ \\
ETS-1 positive tumour cells & 7,04 & 2,43 & 20,36 & $\mathbf{0 , 0 0 0 4}^{*}$ \\
MMP-2 tumour cells & 2,15 & 0,57 & 8,18 & 0,2570 \\
MMP-9 tumour cells & 0,73 & 0,24 & 2,19 & 0,5692 \\
MMP-2 and ETS-1, coexpression & 5,10 & 2,02 & 12,90 & $\mathbf{0 , 0 0 0 7}$ \\
MMP-2, MMP-9 coexpression, & 1,51 & 0,76 & 2,61 & 0,5773 \\
MMP-9 and ETS-1, coexpression & 3,56 & 1,48 & 8,57 & $\mathbf{0 , 0 0 5 0 ^ { * }}$ \\
MMP-2,MMP-9,ETS-1 coexpression & 2,93 & 1,26 & 6,84 & $\mathbf{0 , 0 1 3 3 ^ { * }}$ \\
Positive lymph nodes & 1,58 & 0,61 & 4,09 & 0,3443 \\
ER & 0,69 & 0,29 & 1,65 & 0,3971 \\
PR & 1,32 & 0,57 & 3,05 & 0,5140 \\
HER-2 & 1,15 & 0,42 & 3,18 & 0,7876 \\
Ki67 & 1,21 & 0,66 & 2,21 & 0,5321 \\
Tumour grade 3 & 1,70 & 0,73 & 3,93 & 0,2138 \\
Nuclear grade 3 & 1,80 & 0,78 & 4,18 & 11,696 \\
\hline
\end{tabular}

*-statistically significant $(\mathrm{p}<0,05)$ prognostic value of MMP-2 expression in tumor cells [25]. Scorilas et al. reported potential favourable indicator of MMP9 in node negative patients [22]. These results suggest that further research on the MMP-2 and MMP-9 as a prognostic factor is needed. In our study, expressions of MMP-2, MMP9 and MMP-2/MMP-9 co-expression in tumor cells had no statistically significant impact on OS and DFS (Tables 3 and 4).

Table 4. Influence of investigated data on breast carcinoma patients OS.

\begin{tabular}{lcccc}
\hline & Odds & $\begin{array}{c}95 \% \text { confidence } \\
\text { intervals }\end{array}$ & p \\
\cline { 2 - 4 } & Ratio & low & high \\
\hline Tumour > 2 cm & 3,86 & 1,53 & 9,76 & $\mathbf{0 , 0 0 4 7 ^ { * }}$ \\
Histological grade 3 & 2,84 & 1,16 & 6,96 & $\mathbf{0 , 0 2 3 3 ^ { * }}$ \\
Nuclear grade 3 & 3,00 & 1,22 & 7,39 & $\mathbf{0 , 0 1 7 3 ^ { * }}$ \\
ETS-1 tumour cells & 4,72 & 1,62 & 13,79 & $\mathbf{0 , 0 0 4 9}$ \\
MMP-2 tumour cells & 4,82 & 1,61 & 15,3 & 0,0799 \\
MMP-9 tumour cells & 1,58 & 0,41 & 6,05 & 0,5032 \\
MMP-2, ETS-1, coexpression & 6,93 & 2,36 & 20,34 & $\mathbf{0 , 0 0 0 5}$ \\
MMP-2, MMP9 coexpression & 3,5 & 0,62 & 8,7 & 0,0856 \\
MMP-9, ETS-1, coexpression & 4,29 & 1,62 & 11,36 & $\mathbf{0 , 0 0 3 8 ^ { * }}$ \\
MMP-2,MMP-9,ETS1 coexpression & 4,54 & 1,78 & 11,55 & $\mathbf{0 , 0 0 1 7}$ \\
Positive lymph nodes & 1,99 & 0,72 & 5,50 & 0,1815 \\
ER & 0,55 & 0,22 & 1,37 & 0,1961 \\
PR & 1,20 & 0,49 & 2,93 & 0,6833 \\
HER-2 & 1,23 & 0,42 & 3,59 & 0,6997 \\
Ki67 & 1,72 & 0,93 & 3,17 & 0,0826 \\
\hline * & & & &
\end{tabular}

*- statistically significant $(\mathrm{p}<0,05)$ 
Some of our results in univariate Cox analysis are borderline and show that patients with MMP-2 and MMP-2/MMP-9 co-expression in tumor cells had a tendency toward shorter overall survival but that connection is not statistically relevant ( $p=0,0799$ and 0,0856 respectively).

It is certain that, among many things, ETS- 1 regulates the expression of two gelatinases, MMP-2 and MMP-9. We were not able to find data about correlation of ETS-1, MMP-2 and MMP-9 co-expression with traditional patohistological parameters in breast carcinoma patients, and also we found no studies investigating the influence of their co-expression in tumor cells on OS and DFS. Our data showed that individually collagenases correlate with known histological prognostic factors, co-expression of ETS-1, MMP-2 and MMP-9 significantly correlated with tumor size, nuclear grade, histological grade and hormone receptor status (Table 2). The results of our study showed strong impact of co-expression of ETS-1, MMP-2 and MMP-9 on OS and DFS (Figure 3 and 4). Based on the p-value, multiplexing ETS-1, with MMP-2 and MMP9 does not provide further statistical significance than ETS-1 alone (Table 3). Therefore there is no advantage of multiplexing ETS-1, MMP-2 and MMP-9 as a prognostic marker instead of using ETS-1 alone.

In our immunohistochemical analysis as well as in some other studies ETS-1 positivity has been shown not only in tumor cells but also in stromal cells: lymphocytes, endothelial cells and fibroblasts. According to some authors ETS-1 positivity was high in tumor cells and low in stromal cells $[7,13]$, while some authors put emphasis on stromal elements noting that ETS-1 positivity was higher in stromal elements than in tumor cells $[34,35]$. Further on, it is speculated that tumor cells import MMPs from tumor stroma [20], and therefore it would be of great interest to investigate stromal and tumor co-expression of ETS-1 and gelatinases in breast carcinoma patients and their influence on DFS and OS.

\section{Conclusion}

Our results suggest that ETS-1 is powerful prognostic factor in breast carcinoma patients influencing DFS and OS, and is associated with some other traditional prognostic factors such as tumor size, grade and steroid receptors status. MMP-2 and MMP-9 did not show individually either correlation with traditional prognostic factors or with DFS and OS. Since there are some data implicating influence of ETS-1 in MMP-2 and MMP-9 activation, it can be speculated that MMP-2 and MMP-9 by themselves do not have statistically significant impact, but in combination with ETS-1 might reach statistical significance. At this moment according to our results multiplexing ETS- 1 with MMP-2 and MMP-9 does not provide clinical significance. This fact can serve us to evaluate risk in patients after the surgery treatment analyzing ETS-1 expression to be able to separate group of patients in need of more aggressive adjuvant therapy.

\section{References}

[1] BENSON JR, JATOI I. The global breast cancer burden. Future Oncol 2012; 8: 697-702. http://dx.doi.org/10.2217/fon.12.61

[2] HONRADO E, BENITEZ J, PALACIOS J. The molecular pathology of hereditary breast cancer genetic testing and therapeutic implications. Mod Pathol 2005; 18: 1305-20. http://dx.doi.org/10.1038/modpathol.3800453

[3] SPAN PN, MANDERS P, HEUVEL JJ, THOMAS CM, BOSCH RR et al. Expression of the transcription factor Ets-1 is an independent prognostic marker for relapse-free survival in breast cancer. Oncogene 2002; 21: 8506-9. http://dx.doi. org/10.1038/sj.onc. 1206040

[4] GILLES C, POLETTE M, BIREMBAUT P, BRUNNER N, THOMPSON EW. Expression of c-ets-1 mRNA is associated with an invasive, EMT-derived phenotype in breast carcinoma cell lines. Clin Exp Metastasis 1997; 15: 519-26. http://dx.doi. org/10.1023/A:1018427027270

[5] WASYLYK B, HAHN SL, GIOVANE A. The Ets family of transcription factors. Eur J Biochem 1993; 211: 7-18. http:// dx.doi.org/10.1111/j.1432-1033.1993.tb19864.x

[6] SETH A, WATSON DK. ETS transcription factors and their emerging roles in human cancer. Eur J Cancer 2005; 41: 2462-78. http://dx.doi.org/10.1016/j.ejca.2005.08.013

[7] BUGGY Y, MAGUIRE TM, MCGREAL G, MCDERMOTT E, HILL AD et al. Overexpression of the Ets- 1 transcription factor in human breast cancer. Br J Cancer 2004; 91: 1308-15. http://dx.doi.org/10.1038/sj.bjc.6602128

[8] LI R, PEI H, WATSON DK. Regulation of Ets function by protein-protein interactions. Oncogene 2000; 19: 6514-23. http://dx.doi.org/10.1038/sj.onc. 1204035

[9] HSU T, TROJANOWSKA M, WATSON DK. Ets proteins in biological control and cancer. J Cell Biochem 2004; 91: 896-903. http://dx.doi.org/10.1002/jcb.20012

[10] SHEPHERD T, HASSELL JA. Role of Ets transcription factors in mammary gland development and oncogenesis. J Mammary Gland Biol Neoplasia 2001; 6: 129-40. http://dx.doi. org/10.1023/A:1009576801226

[11] MYLONA EE, ALEXANDROU PT, GIANNOPOULOU IA, RAFAILIDIS PI, MARKAKI S et al. Study of the topographic distribution of ets-1 protein expression in invasive breast carcinomas in relation to tumor phenotype. Cancer Detect Prev 2006; 30: 111-117. http://dx.doi.org/10.1016/ j.cdp.2006.03.006

[12] KARS MD, ISERI OD, GUNDUZ U. Drug resistant breast cancer cells overexpress ETS1 gene. Biomed Pharmacother 2010; 64: 458-462. http://dx.doi.org/10.1016/j.biopha.2010.01.008

[13] KATAYAMA S, NAKAYAMA T, ITO M, NAITO S, SEKINE I. Expression of the ets-1 proto-oncogene in human breast carcinoma: differential expression with histological grading and growth pattern. Histol Histopathol 2005; 20: 119-26.

[14] TOI M, ISHIGAKI S, TOMINAGA T. Metalloproteinases and tissue inhibitors of metalloproteinases. Breast Cancer Res Treat 1998; 52: 113-24. http://dx.doi.org/10.1023/ A:1006167202856

[15] BARRETT JM, PUGILA MA, SiNGH G, TOZER RG. Expression of Ets-related transcription factors and matrix 
metalloproteinase genes in human breast cancer cells. Breast Cancer Res Treat 2002; 72: 227-32. http://dx.doi.org/10.1023/ A:1014993006190

[16] BEHRENS P, ROTHE M, WELLMANN A, KRISCHLER J, WERNERT N. The Ets-1 transcription factor is up-regulated together with MMP 1 and MMP 9 in the stroma of pre-invasive breast cancer. J Pathol 2001; 194: 43-50. http://dx.doi. org/10.1002/path.844

[17] SEMENTCHENKO VI, WATSON DK. Ets target genes: past, present and future. Oncogene 2000; 19: 6533-48. http://dx.doi. org/10.1038/sj.onc.1204034

[18] STETLER-STEVENSON WG, AZNAVOORIAN S, LIOTTA LA. Tumor cell interactions with the extracellular matrix during invasion and metastasis. Annu Rev Cell Biol 1993; 9: 541-73. http://dx.doi.org/10.1146/annurev. cb.09.110193.002545

[19] CHABOTTAUX V, NOEL A. Breast cancer progression: insights into multifaceted matrix metalloproteinases. Clin Exp Metastasis 2007; 24: 647-56. http://dx.doi.org/10.1007/ $\underline{\text { s10585-007-9113-7 }}$

[20] KESSENBROCK K, PLAKS V, WERB Z. Matrix metalloproteinases: regulators of the tumor microenvironment. Cell 2010; 141: 52-67. http://dx.doi.org/10.1016/j.cell.2010.03.015

[21] TALVENSAARI-MATTILA A, PAAKKO P, BLANCOSEQUEIROS G, TURPEENNIEMI-HUJANEN T. Matrix metalloproteinase-2 (MMP-2) is associated with the risk for a relapse in postmenopausal patients with node-positive breast carcinoma treated with antiestrogen adjuvant therapy. Breast Cancer Res Treat 2001; 65: 55-61. http://dx.doi.org/10.1023/ A:1006458601568

[22] SCORILAS A, KARAMERIS A, ARNOGIANNAKI N, ARDAVANIS A, BASSILOPOULOS P et al. Overexpression of matrix-metalloproteinase- 9 in human breast cancer: a potential favourable indicator in node-negative patients. Br J Cancer 2001; 84: 1488-96. http://dx.doi.org/10.1054/ bjoc. 2001.1810

[23] DUFFY MJ, MAGUIRE TM, HILL A, MCDERMOTT E, O'HIGGINS N. Metalloproteinases: role in breast carcinogenesis, invasion and metastasis. Breast Cancer Res 2000; 2 : 252-7. http://dx.doi.org/10.1186/bcr65

[24] KOHRMANN A, KAMMERER U, KAPP M, DIETL J, ANACKER J. Expression of matrix metalloproteinases (MMPs) in primary human breast cancer and breast cancer cell lines: New findings and review of the literature. BMC Cancer 2009; 9: 188. http://dx.doi.org/10.1186/1471-2407-9$\underline{188}$

[25] PELLIKAINEN JM, ROPPONEN KM, KATAJA VV, KELLOKOSKI JK, ESKELINEN MJ et al. Expression of matrix metalloproteinase (MMP)-2 and MMP-9 in breast cancer with a special reference to activator protein-2, HER2, and prognosis. Clin Cancer Res 2004; 10: 7621-8. http://dx.doi. org/10.1158/1078-0432.CCR-04-1061

[26] LI HC, CAO DC, LIU Y, HOU YF, WU J et al. Prognostic value of matrix metalloproteinases (MMP-2 and MMP-9) in patients with lymph node-negative breast carcinoma. Breast Cancer Res Treat 2004; 88: 75-85. http://dx.doi.org/10.1007/ s10549-004-1200-8

[27] TALVENSAARI-MATTILA A, PAAKKO P, TURPEENNIEMI-HUJANEN T. Matrix metalloproteinase-2 (MMP-2) is associated with survival in breast carcinoma. $\mathrm{Br}$ J Cancer 2003; 89: 1270-5. http://dx.doi.org/10.1038/sj.bjc.6601238

[28] TAKI M, VERSCHUEREN K, YOKOYAMA K, NAGAYAMA M, KAMATA N. Involvement of Ets-1 transcription factor in inducing matrix metalloproteinase- 2 expression by epithelialmesenchymal transition in human squamous carcinoma cells. Int J Oncol 2006; 28: 487-96.

[29] VAN DEN STEEN PE, DUBOIS B, NELISSEN I, RUDD PM, DWEK RA et al. Biochemistry and molecular biology of gelatinase B or matrix metalloproteinase-9 (MMP-9). Crit Rev Biochem Mol Biol 2002; 37: 375-536. http://dx.doi. org/10.1080/10409230290771546

[30] BENDRIK C, ROBERTSON J, GAULDIE J, DABROSIN C. Gene transfer of matrix metalloproteinase- 9 induces tumor regression of breast cancer in vivo. Cancer Res 2008; 68: 3405-12. http://dx.doi.org/10.1158/0008-5472.CAN-08$\underline{0295}$

[31] SZABO KA, SINGH G. Modulation of monocyte matrix metalloproteinase- 2 by breast adenocarcinoma cells. Breast Cancer Res 2005; 7: 661-8. http://dx.doi.org/10.1186/bcr1261

[32] CHANG C, WERB Z. The many faces of metalloproteases: cell growth, invasion, angiogenesis and metastasis. Trends Cell Biol 2001; 11: 37-43. http://dx.doi.org/10.1016/S09628924(01)02122-5

[33] NIEMIEC J, ADAMCZYK A, MALECKI K, AMBICKA A, RYS J. Tumor grade and matrix metalloproteinase 2 expression in stromal fibroblasts help to stratify the high-risk group of patients with early breast cancer identified on the basis of st Gallen recommendations. Clin Breast Cancer 2013; 13: 119-28. http://dx.doi.org/10.1016/j.clbc.2012.12.005

[34] WERNERT N, GILLES F, FAFEUR V, BOUALI F, RAES $\mathrm{MB}$ et al. Stromal Expression of c-Ets1 Transcription Factor Correlates with Tumor Invasion. Cancer Res 1994; 54: 5683-5688.

[35] VANDENBUNDER B, QUEVA C, DESBIENS X, WERNERT $\mathrm{N}$, STEHELIN D. Expression of the transcription factor c-Ets1 correlates with the occurrence of invasive processes during normal and pathological development. Invasion Metastasis 1994-1995; 14: 198-209. 